\title{
The Application of Nanomaterials in Cardiovascular Diseases: A Review on Drugs and Devices
}

\author{
Abbas Afrasiabi Rad ${ }^{1}$, Naser Safaei ${ }^{1}$, Sara Salatin ${ }^{2}$, Elham Ahmadian ${ }^{3}$, Simin Sharifi ${ }^{3}$, Sepideh Zununi Vahed ${ }^{4}$, Farzaneh \\ Lotfipour $^{2,5}$, Shahriar Shahi ${ }^{3,6}$, Solmaz Maleki Dizaj ${ }^{3}$ \\ ${ }^{1}$ Faculty of Medicine, Tabriz University of Medical Sciences, Tabriz, Iran; ${ }^{2}$ Faculty of Pharmacy, Tabriz University of \\ Medical Sciences, Tabriz, Iran; ${ }^{3}$ Dental and Periodontal Research Center, Tabriz University of Medical Sciences, Tabriz, \\ Iran; ${ }^{4}$ Kidney Research Center, Tabriz University of Medical Sciences, Tabriz, Iran; ${ }^{5}$ Food and Drug Safety Research Center, \\ Tabriz University of Medical Sciences, Tabriz, Iran; ${ }^{6}$ Faculty of Dentistry, Tabriz University of Medical Sciences, Tabriz, \\ Iran.
}

Received, August 26, 2019; Revised, August 26, 2019; Accepted, September 18, 2019; Published, October 6, 2019.

\begin{abstract}
Cardiovascular diseases (CVDs) are still one of the main causes of death. In recent years, nanotechnology has offered new materials and strategies for more effective and safe treatment as well as diagnosis of CVDs. This review highlights the recent advances in nanotechnology applications in CVD therapy. The manipulation and the production of biomedical implantable devices based on nanomedicine approaches as well as drug delivery concepts for diagnosing and treatment of CVDs are discussed in this paper.
\end{abstract}

\section{INTRODUCTION}

Cardiovascular diseases (CVDs) are generally defined as conditions affecting the heart or blood vessels. It includes all pathologies of the heart and circulatory system such as peripheral vascular disease, coronary heart disease and stroke. CVDs are one of the most significant leading causes of death around the world according to the World Health Organization (WHO) $[1,2]$. Therefore, there is a need for the development of improved treatments for CVDs.

Nanotechnology, as the technology of materials on an atomic, molecular, and supramolecular scale, has shown promises for CVDs application. Nanotechnology is generally defined as the use of nanotechnology in preventing, diagnosing, curing disease or repairing damaged tissues in biological systems [3-7]. In recent years, by improving our understanding of diseases at the molecular level and the development of nanoscale technologies, nanorechnology has witnessed a growth explosion in the world. It is gaining importance for the treatment of CVDs. Nanoparticles, as the particles in the nanometric range, have shown great promises in a wide range of cardiovascular applications [8-10]. Nanoparticles are mobile in both intra- and extravascular systems, making them ideal for the targeted delivery of therapeutics and imaging agents. They have shown significant potential to provide a platform for targeted delivery of drugs because of their unique multi-functionality [11]. Delivering and targeting of drugs to its intended site are the most important characteristics of nanoparticles for the development of successful targeting strategies as well as improved medical imaging technology [9, 12]. Nano-coatings is one of the applications of nanotechnology that improve the medical implants biocompatibility and their incorporation with the surrounding tissues. This technology can be used in dental implants, stent coating in cardiology, and joint replacement implants in orthopedics [9]. Moreover, nanomaterials with antimicrobial activity can be used in wound care, coatings, and medical textiles. Nanoparticles also provide a suitable platform for the functionalization with other molecules, so that several functions can be integrated to nanoparticle. Different types of targeting ligands, like peptides, can be conjugated to nanoparticles for targeting target morbid sites [10]. On the other hand, nanoparticles can be conjugated with functional ligands to evade rapid phagocytic clearance [10,13]. The cellular uptake of nanoparticles allows their new applications for intracellular DNA delivery and RNA detection [14].

Nanoparticles can be taken up into cells through processes such as endocytosis, phagocytosis, and

Corresponding Authors: Solmaz Maleki Dizaj, Golgasht St, Daneshgah Av, Dental and Periodontal Research Center, Tabriz University of Medical Sciences, Tabriz, Iran. Email: malekidizaj@tbzmed.ac.ir 
pinocytosis. From this perspective, the uptake mechanisms of them into different types of cells can be regulated in different ways [15]. Endocytosis and phagocytosis are the specific internalization pathways that are primarily initiated by proteins or receptors. On the other hand, pinocytosis is a nonspecific pathway that occurs when cells absorb the surrounding fluid [16]. These specific and nonspecific pathways of cellular uptake demonstrate that most nanoparticles could enter the cells $[9,10]$. The cellular uptake efficiency of nanoparticles depends on many factors such as size, shape, surface charge, morphology, density, decoration, and agglomeration of nanoparticles [15].

Over the past decades, a wide variety of nanostructure systems have been designed for drug delivery and in fabrication of biomedical implantable devices [1, 9, 10, 17]. Nanomaterials offer extraordinary openings for overcoming the restrictions of conventional biomaterials. The nanostructured surfaces of nanomaterials can improve the performance and action of conventional biomaterials. Besides, the development of nanomaterials can motivate a number of novel therapeutic approaches which could modernize the treatment of CVDs. Biomedical implants provide a broad range of options for treating the disorders, like CVDs. Heart valves, defibrillators, vascular grafts, pace markers and stents are examples of commonly used cardiovascular implantable devices in the field of medicine. Besides, delivering and targeting of drug to its intended site are the most important characteristics of them in the treatment of CVDs $[10$, 17].

This review highlights the recent advances in nanotechnology application in cardiovascular therapy. The manipulation and the fabrication of biomedical implantable devices based on nanomedicine approaches as well as drug delivery concepts are also discussed in this paper.

\section{THE ACTIVE SURFACE OF NANO- MATERIALS}

Nanostructures have long been known to have unique surface and physicochemical characteristics such as a surface area to volume ratio, surface energy, surface roughness, wettability, and reactivity that can be adapted to promote improvement in the mechanical performance and biological response of biomaterials. The nanostructured surfaces can be classified into "well-ordered nanostructures" and "random nanostructures". In addition to the advantages mentioned above, the ordered surface nanostructures exhibit more potent effects on cell activities as compared with the random nanostructures, for example improving cell alignment based on the principle of contact guidance [31].

Incorporation of the nanostructured surface into conventional materials that have been applied to many implants and other devices are approved by regulatory agencies, The development of novel materials and therapeutic agents requires large and long trials toward approval. For instance, traditional drug-eluting stents can cause some complications owing to the side effects of anti-proliferative and anti-inflammatory drugs, which delay endothelialization. However, whether nanopatterning on an approved material can significantly replace the anti-proliferative drugs or not, certainly merits intensive researches $[1,10,17,18]$.

Inserting nano-features on the surface by means of nanomaterials is a complicated process [19]. The surface of biomaterials allows an interface between the device and the human body. Nano-features on materials surface can affect the biological responses at the cellular and tissue level because of similar dimension, thereby improving the direct interactions with proteins and biological molecules in the body. The recent advances in nanotechnology enable the precise fabrication of different nanostructures on materials surface with applications in therapeutic devices like reservoirs for cells or drugs. Therefore, it may be possible to use special modified nanosurfaces to induce appropriate biological responses to the devices $[7,10,18]$.

The physicochemical possessions as well as chemical composition of the surrounding environment perform very significant roles in cellmaterial interactions. In the body, the extracellular matrix is the main surrounding environment of cells [20]. When a nanomaterial with a nanostructured surface introduces into the body, its special features may influence proteins and also affect cell adhesion, proliferation, differentiation and phenotype. These features may include surface energy, surface area, surface roughness, wettability, electrical charge, topography, morphology, chemical composition and mechanical properties. For instance, based on reports a nanorough surface shows more vitronectin on the surface and leads to a greater cell adhesion that could be a satisfactory event or an opposing occurrence depending on the applications [21]. Thus, for cardiovascular stents it may lead to increased 
adhesion of endothelial cells as the desired event for fast endothelialization, or promoted adhesion and growth of smooth muscle cells by enhancing formation of neointima and blocking of vessel lumen [22].

\section{NANOPARTICULATE SYSTEMS FOR TREATMENT AND DIAGNOSIS OF CVDS}

Nanoparticles have shown significant potential to provide a platform for targeted delivery of drugs because of their unique multi-functionality. Delivering and targeting of drug to its intended site are the most important characteristics of nanoparticles [4, 23-25].

\section{Targeted drug delivery of nanomaterials to treat CVDs}

Biodegradable polymers such as poly(lactide) (PLA), poly(lactide-coglycolide) copolymers (PLGA), poly( $\varepsilon$-caprolactone) (PCL), and poly(amino acids) have been used for preparation of different types of polymeric nanomaterials for drug delivery application [26-32]. These types of nanoparticles have also been reported to be used as the delivery system in CVDs. In 1997, Labhasetwar et al. studied the effectiveness of nano-polymeric drug delivery systems for the treatment of restenosis in an ex-vivo arterial model. The poly (lactide-coglycolide) (PLGA) polymeric nanoparticles were prepared and their surfaces were modified by a cationic agent. This study revealed that the arterial uptake of surface coated nanoparticles was higher (10-time) than the non-coated once. That study provided, for the first time, a basis to integrate nanocarriers on stent surfaces for treatment of restenosis [33]. In another experiment, the same research group produced new formulations of polymeric nanoparticles of anti-restetonic drugs. They found that the arterial uptake was sizedependent as the small diameter of particles ( $c a .100$ $\mathrm{nm})$ penetrated better than large diameter $(200 \mathrm{~nm})$ into the ex-vivo model of dog carotid artery. They observed that $26 \%$ of the nanoparticles can be retained when the artery was not washed; however, washing with Ringer's solution resulted in a $6 \%$ drop in retaining nanoparticles, indicating that the stent surface nanoparticles can be washed away via vascular flow [34]. This group also examined the arterial retaining of the polymeric nanoparticles in porcine coronary arterials model and endothelial cells. In comparison to ex vivo model, in this in vivo model, a drop was found on the uptake capacity of nanoparticles. Moreover, the designed nanoparticles were localized in the cytoplasm of the cells preferentially and the smaller sized nanoparticles (70 $\mathrm{nm}$ ) had a higher uptake (27-fold) than $200 \mathrm{~nm}$ diameter nanoparticles. Likewise, Luderer et al. prepared a diameter of $250 \mathrm{~nm}$ sirolimus-loaded poly (D, L-lactide) nanoparticles that were more effective than the free drug to prevent the proliferation of smooth endothelial cell with no effect on the endothelial cell multiplication [35].

Quercetin, as an antioxidant, has reported to show protection effect against CVDs. A recent study by Giannouli et al. showed the promising efficiency of PLGA loaded with quercetin for atherosclerosis prevention with high encapsulation efficiencies and suitable drug release performance indicating their possibility to protect against CVDs. Their group is working on in vitro and in vivo potential of these particles [36].

As it is well known, nitric monoxide (NO) can mediate functions of vascular smooth muscle and endothelium cells. It is reported that DNA synthesis of smooth muscle cells can be inhibited by NOreleasing polymers. Polizzi and co-workers developed modified (polyamine-protected) gold nanoparticles in the size of 3-5 $\mathrm{nm}$ by choosing two different ligands (tiopronin and polyamine) for controlled and targeted delivery of NO. NO was functionalized into ligands. The inherent water solubility of both tiopronin and polyamine protected nanoparticles offer their potential for biological/medicinal applications. Based on their report, the prepared monolayer-protected gold clusters (MPCs) significantly enhanced NO payloads using both ligands. Besides, the existence of amine as protecting ligand let tunable NO-release performance. Furthermore, the prepared MPCs offers a multivalent surface for use in consequent delivery options. The authors believed that more studies are needed to modify the cationic primary amine functional groups with charge-neutral groups to eradicate the potential toxicity related to the amines and/or damaging nitrosamine formation following NO release [37].

Apart from being a platform for functional groups, the drugs can also be loaded by nanoparticles. Liposomes are significant candidates as vehicles for the encapsulation of CVDs drugs. Danenberg and co-workers demonstrated that clodronate-loaded liposomes can significantly reduce neointimal hyperplasia after balloon injury in 
rat and rabbit models [38]. The involvement of platelet aggregation in the pathogenesis of CVDs such as atherosclerosis, myocardial infarction and thrombosis, has turned platelets into important targets in liposomal drug delivery systems to tackle the mentioned disorders [39].

Intermittent claudication and other peripheral arterial diseases could also be treated via the application of liposomes. The ongoing phase III clinical trial in the use of liposomes in the delivery of prostaglandin E-1 (PGE-1), under the trade name of Liprostin, is a robust prove in the implementation of this drug delivery system [40]. Liprostin possesses several pharmacological specifications such as inhibition of platelet aggregation, prohibition of leukocyte adhesion and inflammatory cascade and induction of vasodilatory effect [41]. Encapsulation of PGE-1 with lipid nanoparticles has both diminished the degradation of the drug and increased its therapeutical efficacy [41]. Targeted treatment of thrombosis has been reported via the application of liposomes. The latter is the obstruction of the blood vessels which is in close relationship with myocardial infarction. A recent work has reported a cyclic arginyl-glycyl-aspartic acid (cRGD) surfacefunctionalized peptide which contains the antithrombosis drug, urokinase, in a liposome carrier. The cRGD peptide selectively binds onto active platelet-placed GPIIb//IIIa receptors. In an animal thrombosis model, this liposome showed parallel effects to the free urokinase at $75 \%$ less drug dosage [42].

Polymeric micelles have also been investigated as CVDs drug delivery systems. The hydrophobic core of micelles regulates the encapsulation of pharmaceutical compounds, and the hydrophilic nature of shell enhance circulation time of micelles $[43,44]$. The small size allows micelles to pass through biological membranes for entry into tissues [44]. Polymeric micelles are more stable when compared to the liposomes and low-molecularweight surfactants due to their significantly low ratios of excipient to the drug. Hence, these carrier vehicles not only show a very low risk of systemic toxicity but also are cost-effective. Besides, the synthesis of micelles is highly controllable, and they can easily be tailor made to achieve more effective therapies by the addition of targeting or tracking molecules. The most common types of polymers utilized for the preparation of micelles are comprised of poly (amino acid) or polyester derivatives to form hydrophobic regions [45]. In a recent study, the micelles were fabricated using a block copolymer of polycaprolactone-b-poly(2- (dimethylamino) ethyl methacrylate) (PCL-PDMAEMA), and a block copolymer of methoxy polyethylene glycol- bpolycaprolactone (mPEG-PCL) mixed with a block copolymer of polycaprolactone-b-polyethylene glycol with an RGD peptide conjugated (PCL-PEGRGDfk) to develop a delivery system of lumbrokinase (LK) loaded targeted micelles (LKTM). The in vivo study of thrombosis in mice model has shown that mice treated with LKTM exhibit a markedly lower tail bleeding time than those treated with LK alone or the LK micelles without targeting. These results suggest that the developed LKTM can effectively reduce the risk of bleeding [46]. Some samples of conventional formulations and nanomedicines in the market were shown in Table 1.

\section{Nanomaterials in diagnostic of in CVDs}

Nanoparticles can be used in diagnostic areas of CVDs due tp their targeting property to reach particular morbid sites for detected. The use of nanoparticles in the early detection of atherosclerosis is a good example.

To attain this goal, Nahrendorf and coworkers used mono-crystalline magnetic nanoparticles (MNPs) for noninvasive detecting of vascular cell adhesion molecule-1 (VCAM-1), an indicator of inflammation [48]. In their study, the multivalent MNPs were functionalized with a peptide that could target the MNPs to the VCAM-1 expressing cells. The MNPs can determine occurrence and degree of inflammation, providing the possibility to detect early-stage atherosclerosis [48].

Nanoparticles have been applied to improve magnetic resonance imaging (MRI) diagnosis. Due to their targeting function they can be used as perfect contrast agents for MRI. One successful example for the application of this technique is imaging of rejection site after transplantation of rat cardiac allograft [49]. Kanno and coworkers designed novel dextran-coated ultra-superparamagnetic nanoparticles of iron oxide. The signal generated by successfully labeled macrophages with magnetic particles showed the degree and location of rejection [49]. Given that macrophages can be successfully identified, the inflammatory responses and foreign body responses can also be assessed in several other cardiovascular-related conditions by means of similar technologies in the future. 
Table 1. Conventional drugs and nanomaterials for CVD therapy [47].

\begin{tabular}{llll}
\hline The drug name & The type of drug & Conventional form & New formulation based on nanomaterials \\
\hline $\begin{array}{l}\text { Isosorbide } \\
\text { monohydrate }\end{array}$ & Lipid increasing & $\begin{array}{l}\text { Monoket long retard tablet } 40 \mathrm{mg} \\
\text { (Adeka, Turkey) - Monodur tablet } \\
60 \mathrm{mg} \text { (Astra Zeneca, Canada) }\end{array}$ & $\begin{array}{l}\text { Mono corax micropellet capsule 60 mg } \\
\text { (corax, Germany) - Monisol micropellet } \\
\text { capsule 60 mg (Zorka, Russia) -Monitan } \\
\text { micropellet capsule 60 mg (Wyeth, Canada) }\end{array}$ \\
$\begin{array}{llll}\text { Diltiazem } \\
\text { hydrochlorate }\end{array}$ & Antihypetensive & $\begin{array}{l}\text { Diltiazem ampoule 25 mg (Mustafa } \\
\text { Nevzat, Turkey). }\end{array}$ & $\begin{array}{l}\text { Altiazem SR micropellet 60 mg (Nobel, } \\
\text { Turkey) - Dilatam SR micropellet 60 mg } \\
\text { (Abic, Israel) - Coramil SR micropellet 60 } \\
\text { mg ( Sanofi, Sweden) }\end{array}$ \\
& Lipid increasing & $\begin{array}{l}\text { Lipidil tablet 200 mg (Fournier, } \\
\text { Germany, Canada) } \\
\text { Lipofene tablet 200 mg (Teofarma, } \\
\text { Italy) }\end{array}$ & $\begin{array}{l}\text { Lipofene SR micropellet 250 mg (Nobel, } \\
\text { Turkey) }\end{array}$ \\
& & $\begin{array}{l}\text { Feno-micro micropellet 250 mg (Apotex, } \\
\text { Hungary) }\end{array}$ \\
\hline
\end{tabular}

Generally, theranostic nanoparticles are designed as a platform with imaging and therapeutic functions [50]. In a study, McCarthy et al. [110] fabricated dextran-coated magnetofluorescent nanoparticles conjugated with a photosensitizer to target plaque macrophages. Upon light of particular wavelength range, the photosensitizer can release oxygen singlet and subsequently oxygen kill macrophages. The detection technologies and killing of macrophages has been considered to play significant roles in future diagnosis and therapy of atherosclerosis [51]. Notably, the integration of diagnostic and therapeutic functions into a single nanoparticle platform may empower successful applications in targeted delivery of drugs. Different strategies in the use of nanoparticles in CVDs diagnosis is summarized in Table 2 .

\section{NANOMATERIALS IN CVDS DEVICES}

In the past decades, nanotechnology-based systems have provided new possibilities to develop new devices to treat CVDs. A stent is a tubular device which is applied to support a segment of a blood vessel or any other anatomical lumen while maintaining the region's patency. Before the introduction of coronary stents as bare metallic stents, balloon angioplasty was the most common option to bypass the blocked vascular vessels [52, 53]. However, balloon angioplasty and stent implantation can still cause damage and other complications such as platelet aggregation, vascular smooth muscle cell migration, elastic recoil, and at last thrombus formation [52]. These problems may be overcome by the suitable modification of the stent surface and amended by the introduction of therapeutic agents. For this, stents have been fabricated with their surface coated with matrix polymers bearing therapeutic compounds.. Some of the most common surface modifiers applied for the surface coating and the developing of the drug eluting stents include biolimus-, everolimus-, Sirolimus-, and paclitaxel-polymer combinations [54, 55]. Among these, sirolimus-eluting CYPHER ${ }^{\circledR}$ and paclitaxel-eluting TAXUS ${ }^{\circledR}$ have been used by many researchers. The clinical studies have exhibited that these systems offer their therapeutic efficacies by reducing the risk of in-stent restenosis [56, 57].

Different devices used in the cardiovascular field need to have a unique combination of nanomaterial's features to guarantee a cost-effective construction, effective use and degradable manner over time without adverse effects. There are two general approaches for the use of nanomaterials in CVDs related devices. The first approach is the nanocoating that improvs the medical implants biocompatibility and their incorporation with the surrounding tissues. The use of nanostructured materials in mimicking naturally occurring structures is another trend that results in improved physical, mechanical, and biological features of implants [9]. 
Table 2. Different strategies in the use of nanoparticles in CVDs diagnosis

\begin{tabular}{|c|c|c|c|c|c|}
\hline The strategies & $\begin{array}{l}\text { The examples } \\
\text { nanomaterials }\end{array}$ & The method & $\begin{array}{l}\text { Type of } \\
\text { experimen } \\
\mathrm{t} \text { and } \\
\text { species }\end{array}$ & The main finding(s) & Reference(s) \\
\hline $\begin{array}{l}\text { Contrast } \\
\text { agents for } \\
\text { MRI }\end{array}$ & $\begin{array}{l}\text { Dextran-coated } \\
\text { ultra- } \\
\text { superparamagnetic } \\
\text { nanoparticles of } \\
\text { iron oxide }\end{array}$ & $\begin{array}{l}\text { Combination of } \\
\text { nanoparticles with } \\
\text { MRI technology for } \\
\text { imaging of rejection } \\
\text { site after } \\
\text { transplantation of } \\
\text { rat cardiac allograft. }\end{array}$ & In vivo, rat & $\begin{array}{l}\text { Macrophages successfully } \\
\text { identified, the inflammatory } \\
\text { responses and foreign body } \\
\text { responses also assessed. }\end{array}$ & [49] \\
\hline $\begin{array}{l}\text { Conjugated } \\
\text { with imaging } \\
\text { and } \\
\text { therapeutic } \\
\text { functions, } \\
\text { helping to } \\
\text { realize the } \\
\text { definition of } \\
\text { personalized } \\
\text { medicine }\end{array}$ & $\begin{array}{l}\text { Dextran-coated } \\
\text { magnetofluorescent } \\
\text { nanoparticles } \\
\text { conjugated with a } \\
\text { photosensitizer }\end{array}$ & $\begin{array}{l}\text { To target plaque } \\
\text { macrophages. Upon } \\
\text { light of particular } \\
\text { wavelength range, } \\
\text { the photosensitizer } \\
\text { can release oxygen } \\
\text { singlet. }\end{array}$ & $\begin{array}{l}\text { In vitro, } \\
\text { RAW } \\
264.7 \text { and } \\
\text { U937 } \\
\text { macropha } \\
\text { ge cell } \\
\text { lines }\end{array}$ & $\begin{array}{l}\text { The photosensitizer can release } \\
\text { oxygen singlet and subsequently } \\
\text { oxygen kill macrophages. }\end{array}$ & {$[51]$} \\
\hline
\end{tabular}

\section{Nano-coating of CVDs devices}

Nano-coatings can be used in dental implants, stent coating in cardiology, and joint replacement implants in orthopaedics. Moreover, nanomaterials antimicrobial activity can be used in wound care, coatings, and medical textiles [7, 49, 52]. Westedt et $a l$. have who designed a catheter balloon coated by nanoparticles that locally releases the nanocarriershave observed higher arterial uptake of the fluorescent labeled nanoparticles [58]. Nanoparticle-eluting metallic stents coated with chitosan are reported by Nakano et al.. Chitosan coating caused electrodeposition and provided a cationic surface charge to the nanoparticles. The surface interacts with the negative charge of cellular membranes and fascilitates intracellular uptake of nanoparticles. An in vivo experiment has shown that stents that are coated by fluorescein isothiocyanate (FITC)-encapsulated nanoparticles have improved fluorescence in media layers and neo-intima in comparison to solely (FITC) -polymer coated stents [59].

Joo et al. developed a novel "Ring Shaped Surface Tension Method" to coat PLGA nanoparticles on the surfaces of stents based on the fact that as a result of capillarity, a liquid can be held between two closely spaced surfaces in the form of a meniscus [60]. The scanning electron microscopy images clarified that the nanoparticles could be deposited uniformly and closely on stents and the 
nanoparticles layers could sustain the layer structures by their physical strength [60].

\section{Nanostructured CVDs devices}

In spite of the fact that the coating of the surface of the stents by drug-polymer matrix has solved the instent restenosis problems, a new critical problem still exist, ie., the late stent thrombosis. This partly occurs as the human body detects the stent surface as a foreign substance, and/or as the incorporated polymers may cause inflammation despie its biodegradable nature, and result in [61]. Thus, researchers have continued to search for new ways using nanotechnology. Nanomaterials application in mimicking naturally occurring structures is another trend that results in improved physical, mechanical, and biological features of implants. This approach provides the potential for problem solving by promoting the endothelial cells proliferation and suppressing the proliferation of vascular smooth muscle cells. Nanostructured stents seem to be most effective for the treatment of CVDs than nanocarrier coating-based stents. The nanoparticles associated with stents leave the stent surface, penetrate to the damaged epithelium and are then internalized into the arterial tissues [62].

A great deal of medical research has also been devoted to the fabrication of nanostructured biomedical implant made through surface topography. Reed et al. have reported the first study in this context [63]. Their study assessed the integration of a microvascular apparatus in vascular coronary stents which pierces the plaque and facilitates the delivery of antirestenotic agents into the coronary artery. But, the mentioned system, unlike the nanoparticles did not transport the drugs into the arterial layers. However, in another study, this problem was solved using a polymer stent coating by selecting a composite coating of nanotubes [64]. In a surrogate approach, nanotoplogy was incorporated as a substitute of nanotube coatings on a metallic stent surface [65]. The major complication of these stents is a generation of polymer-related thrombosis which could be inhibited via using a polymer-free surface. Also, bare metallic stents has shown lower rates of thrombosis formation than drug-eluting stents [65].

Designing fully metallic nanostructured-wires is the target of many studies. Favorable surface specifications which are the result of chemically etching surfaces could be achieved through high temperature chemical vapor deposition method.
Radio frequency plasma which is capable of inducing radially stemming metallic nanopillar constructions on stent surfaces has been utilized in recent years providing a porous and dense structure that influences endothelial cells [66]. Also, these metallic nano-compartments plunge the risk of thrombus generation and thus enhance the safety margin of the stents via implementing a polymer-free approach. Additionally, stents containing metallic nanostructured surfaces might plausibly facilitate the reuse of bare metallic stents [67].

The interaction between stents and endothelial cells and also the impact of stents on the endothelialization process are the major factors before deciding on the stent designing and synthesis method. In a study conducted by Jia et al, the efficiency of nanosized stainless steel stents on the mechanisms of endothelialization process was studied [68]. These stents were loaded with paclitaxel. The results obtained from in vivo studies demonstrated that the above-mentioned stents accelerated the re-endothelialization process, improved vessel healing and plummeted the inflammatory cascade in comparison with polymer based sirolimus stents or a bare metallic one. Figure 1 depicts the advantages of nanomaterials in CVD devices. Table 3 also summarizes the nanotechniques and the nano-drugs used for CVD treatment.

\section{TOXICITY OF NANOMATERIALS}

In comparison with other types of materials, nanoparticles toxicity may be more important due to their mobility in the body. In cases that well-known safe biocompatible materials are used as the matrix for nanocomposites, emerging toxic effects can mostly be attributed to the nanoparticle nature of the components. Some studies have reported that different varieties of nanoparticles possess cytotoxic activities despite growing body of literature focusing on the importance of nanoparticles in cardiovascular applications [69-71]. For instance, it has been reported that ultra-small superparamagnetic iron oxide nanoparticles can induce myocardial toxic effects such as thrombosis in vivo, platelet aggregation, nucleic acid damage, and cardiac reactive oxygen species formation [84]. Pulmonary and cardiovascular injuries have also been observed subsequent to the application of zerovalent iron nanoparticles. Exposure of human A549 alveolar epithelial cells and EA.hy926 vascular endothelial cells to nano-structured 
zerovalent iron coincides within the increment of oxidative hazard in vitro. Besides, the toxicity was in relation to the secretion of inflammatory mediators in alveolar epithelial cells [85]. In spite of the utmost potentials of iron nanoparticles in biomedical use, their safety in human body and environment should be tested before marketing. This concern is also valid for carbon nanoparticles and nanotubes (CNT) since several side effects have been reported regarding their biological application. Aortic endothelial cells have shown decreased viability after treatment with single wall CNT (SWCNT) or double wall CNT (DWCNT) [53]. Also, increased direct monocyte adhesion to endothelial cells which initiate atherosclerosis has been shown after administration of either SWCNTs or DWCNTs in mice [53]. Atherosclerotic plaque can itself pave the wave for other cardiovascular diseases. Increased acute phase protein which is a marker of cardiovascular diseases has been enhanced in plasma after Multi-walled carbon nanotubes (MWCNTs) treatment [86].
Biocompatible or bio-inert nanomaterials such as gold nanoparticles have also been shown to have the ability to cause toxicities including DNA damages [87]. Undoubtedly, the toxicity profile of a certain nanomaterial to be utilized in regenerative medicine or tissue engineering has pivotal importance. This toxicity could occur in extracellular and intracellular levels resulting in a wide range of disturbance in signaling cascades. Regardless of the excellent properties in any synthetized nanomaterial, evaluation of its possible toxicity is strongly required before any biomedical implementation. In spite of the reported toxic effects of nanomaterial which serve as novel incorporations in cardiovascular regenerative therapy, the newness of this filed should be taken into account. Future research is needed to fully investigate the toxicity in particular hemotoxicity and inflammatory responses. Also, introduction of new approaches to diminish the toxicity should be the aim of upcoming studies [88].

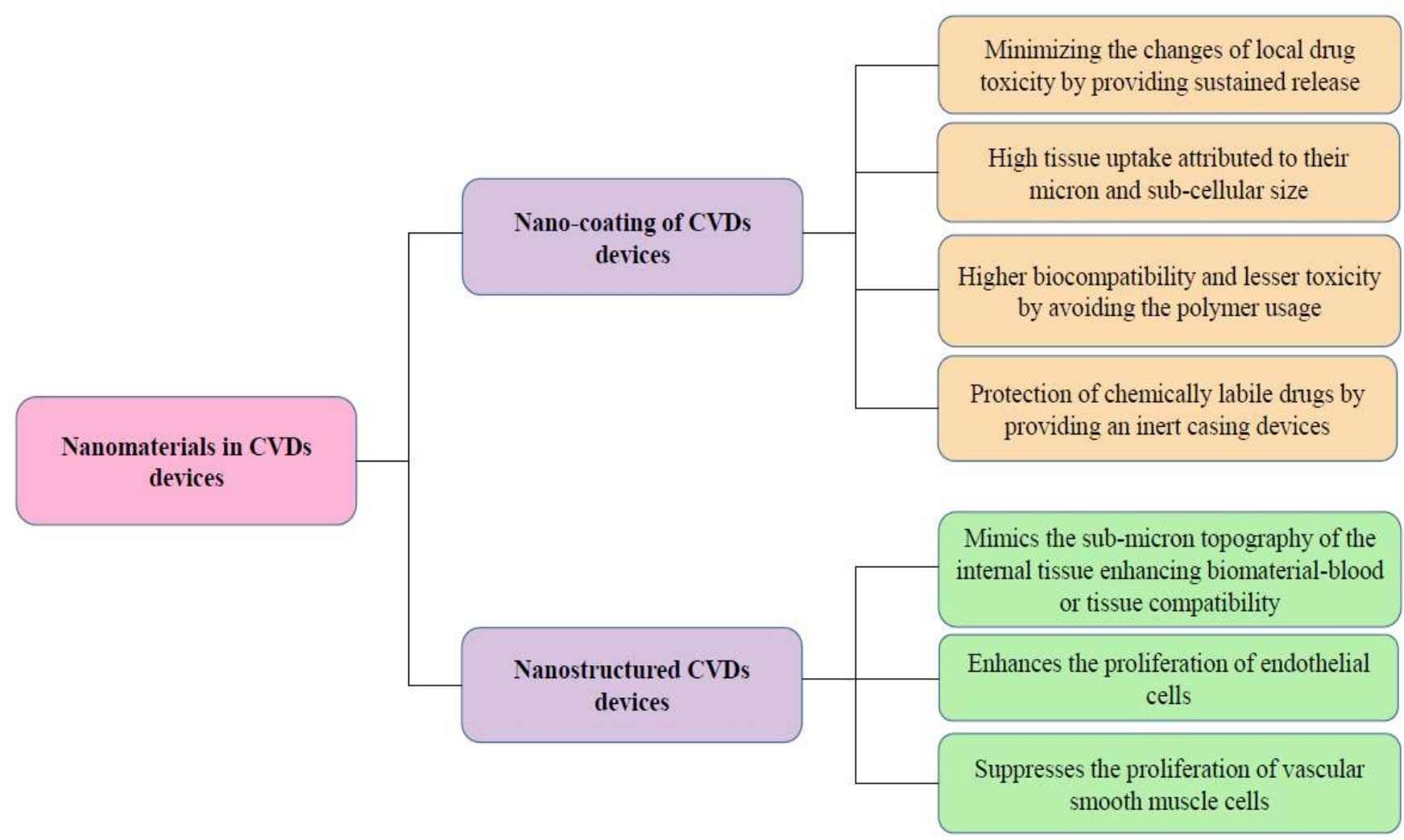

Figure 1. The advantages of nanomaterials in CVD devices. The data adopted from [9]. 
Table 3. The nano-techniques and the nano-drugs used for CVD treatment

\begin{tabular}{|c|c|c|c|c|c|c|}
\hline Techniques & $\begin{array}{c}\text { Nanoparticulate } \\
\text { system }\end{array}$ & $\begin{array}{l}\text { Preparation } \\
\text { technique }\end{array}$ & Type of drug & The used method & The main findings & Ref. \\
\hline $\begin{array}{l}\text { Targeted } \\
\text { drug } \\
\text { delivery }\end{array}$ & $\begin{array}{l}\text { Superparamagnetic } \\
\text { iron- } \\
\text { hydroxyapatite } \\
\text { NPs }\end{array}$ & $\begin{array}{l}\text { Oxidative } \\
\text { process }\end{array}$ & $\begin{array}{l}\text { Ibuprofen as a } \\
\text { model drug }\end{array}$ & $\begin{array}{l}\text { The biological } \\
\text { effects on the } \\
\text { cardiac system of } \\
\text { the identified } \\
\text { electromagnetic } \\
\text { exposure were } \\
\text { assessed in vitro } \\
\text { and in vivo by } \\
\text { acute stimulation } \\
\text { of isolated adult } \\
\text { cardiomyocytes } \\
\text { and in rat. }\end{array}$ & $\begin{array}{l}\text { No alterations of } \\
\text { cardiac } \\
\text { electrophysiological } \\
\text { properties were } \\
\text { observed in both } \\
\text { cases, providing the } \\
\text { evidence that the } \\
\text { combination of } \\
\text { low-frequency } \\
\text { magnetic } \\
\text { stimulations and } \\
\text { FeHAs might } \\
\text { represent a } \\
\text { promising strategy } \\
\text { for controlled drug } \\
\text { delivery to the } \\
\text { failing heart. }\end{array}$ & {$[72]$} \\
\hline $\begin{array}{l}\text { Targeted } \\
\text { drug } \\
\text { delivery }\end{array}$ & $\begin{array}{l}\text { Porous silicon NPs } \\
\text { functionalized with } \\
\text { atrial natriuretic } \\
\text { peptide }\end{array}$ & $\begin{array}{l}\text { Electrochemical } \\
\text { anodization }\end{array}$ & $\begin{array}{l}\text { Trisubsituted- } \\
3,4,5- \\
\text { isoxazole }\end{array}$ & $\begin{array}{l}\text { Targeted drug } \\
\text { delivery into the } \\
\text { endocardial layer } \\
\text { of the left } \\
\text { ventricle for } \\
\text { cardiac repair in } \\
\text { the ischemic } \\
\text { heart. }\end{array}$ & $\begin{array}{l}\text { Improved colloidal } \\
\text { stability and } \\
\text { enhanced cellular } \\
\text { interactions with } \\
\text { cardiomyocytes and } \\
\text { non-myocytes with } \\
\text { minimal toxicity for } \\
\text { nanoparticles and } \\
\text { increased } \\
\text { accumulation of } \\
\text { ANP-PSi } \\
\text { nanoparticles in the } \\
\text { ischemic heart, } \\
\text { particularly in the } \\
\text { endocardial layer of } \\
\text { the left ventricle. }\end{array}$ & [73] \\
\hline $\begin{array}{l}\text { Targeted } \\
\text { drug } \\
\text { delivery }\end{array}$ & $\begin{array}{l}\text { Anti-CD31 } \\
\text { antibodies } \\
\text { conjugated PLGA } \\
\text { NPs }\end{array}$ & $\begin{array}{l}\text { Double } \\
\text { emulsion- } \\
\text { solvent } \\
\text { evaporation }\end{array}$ & $\begin{array}{l}\text { 4- } \\
\text { hydroxytamoxifen }\end{array}$ & $\begin{array}{l}\text { Targeted drug } \\
\text { delivery into } \\
\text { endothelial cells } \\
\text { with tissue- } \\
\text { specific } \\
\text { antibodies. }\end{array}$ & $\begin{array}{l}\text { Increased ability for } \\
\text { targeted delivery } \\
\text { and enhanced } \\
\text { uptake within } \\
\text { endothelial cells. }\end{array}$ & [74] \\
\hline $\begin{array}{l}\text { Targeted } \\
\text { drug } \\
\text { delivery }\end{array}$ & $\begin{array}{l}\text { Atrial natriuretic } \\
\text { peptide modified } \\
\text { lipid nanocarriers }\end{array}$ & $\begin{array}{l}\text { Solvent } \\
\text { evaporation }\end{array}$ & $\begin{array}{l}\text { Oleate adenosine } \\
\text { prodrug }\end{array}$ & $\begin{array}{l}\text { In vivo inhibition } \\
\text { effect on infarct } \\
\text { size, tissue } \\
\text { distribution, and } \\
\text { pharmacokinetics } \\
\text { in rats with } \\
\text { ischemic } \\
\text { myocardium after } \\
\text { intravenous } \\
\text { injection. }\end{array}$ & $\begin{array}{l}\text { Long-circulating } \\
\text { characteristics of } \\
\text { NPs than that of } \\
\text { free drug and } \\
\text { targeted ability into } \\
\text { the infarct } \\
\text { myocardium in a } \\
\text { receptor-dependent } \\
\text { manner. }\end{array}$ & [75] \\
\hline
\end{tabular}




\begin{tabular}{|c|c|c|c|c|c|c|}
\hline Diagnosis & $\begin{array}{l}\text { Dextranated and } \\
\text { DTPA-modified } \\
\text { magnetofluorescent } \\
\text { NPs labeled with } \\
\text { the PET }\end{array}$ & Metal reduction & - & $\begin{array}{l}\text { PET-CT imaging } \\
\text { of macrophages in } \\
\text { inflammatory } \\
\text { atherosclerosis. }\end{array}$ & $\begin{array}{l}\text { Improved } \\
\text { sensitivity and } \\
\text { cellular distribution. }\end{array}$ & [76] \\
\hline Diagnosis & $\begin{array}{l}\text { VCAM-1-modified } \\
\text { fluorescent } \\
\text { magnetic NPs }\end{array}$ & Metal reduction & - & $\begin{array}{l}\text { Targeting of NPs } \\
\text { into endothelial } \\
\text { cells in a murine } \\
\text { tumor necrosis } \\
\text { factor- } \alpha \text {-induced } \\
\text { inflammatory } \\
\text { model. }\end{array}$ & $\begin{array}{l}\text { High cellular } \\
\text { specificity of the } \\
\text { parent NPs and } \\
\text { targeted imaging of } \\
\text { activated } \\
\text { endothelium. }\end{array}$ & [77] \\
\hline Diagnosis & $\begin{array}{l}\text { Folate-conjugated } \\
\text { porphyrin NPs }\end{array}$ & - & - & $\begin{array}{l}\text { In vivo tracking of } \\
\text { Folate- } \\
\text { porphysome } \\
\text { cardiac } \\
\text { macrophage using } \\
\text { radioligand and } \\
\text { fluorescent } \\
\text { imaging in mice. }\end{array}$ & $\begin{array}{l}\text { Non-invasive } \\
\text { imaging of } \\
\text { macrophages and } \\
\text { monitoring of } \\
\text { active macrophage } \\
\text { behavior in the } \\
\text { infarcted heart. }\end{array}$ & [78] \\
\hline Diagnosis & $\begin{array}{l}\text { Annexin A5- } \\
\text { conjugated } \\
\text { micellar NPs }\end{array}$ & $\begin{array}{l}\text { Covalent } \\
\text { conjugation }\end{array}$ & - & $\begin{array}{l}\text { In vivo imaging of } \\
\text { the abdominal } \\
\text { aorta in } \\
\text { atherosclerotic } \\
\text { ApoE-/- mice. }\end{array}$ & $\begin{array}{l}\text { Targeted delivery } \\
\text { into macrophages } \\
\text { and apoptotic cells } \\
\text { with enhanced } \\
\text { cellular uptake. }\end{array}$ & [79] \\
\hline $\begin{array}{l}\text { Nano } \\
\text { structured } \\
\text { device }\end{array}$ & $\begin{array}{l}\text { Polymer-free } \\
\text { paclitaxel-eluting- } \\
\text { stent with a } \\
\text { nanoporous surface }\end{array}$ & - & Paclitaxel & $\begin{array}{l}\text { Endothelialization } \\
\text { and inhibition of } \\
\text { neointimal } \\
\text { hyperplasia in a } \\
\text { porcine model. }\end{array}$ & $\begin{array}{l}\text { Targeted delivery } \\
\text { into the local } \\
\text { coronary artery and } \\
\text { desirable drug- } \\
\text { elution properties. }\end{array}$ & [61] \\
\hline $\begin{array}{l}\text { Nano } \\
\text { structured } \\
\text { device }\end{array}$ & $\begin{array}{l}\text { A nanocomposite } \\
\text { polymer with a } \\
\text { PCU and POSS } \\
\text { NPs }\end{array}$ & Cross-linking & - & $\begin{array}{l}\text { In vitro evaluation } \\
\text { of the mechanical } \\
\text { properties of the } \\
\text { nanocomposite } \\
\text { polymer as } \\
\text { material for a } \\
\text { synthetic leaflet } \\
\text { heart valve. }\end{array}$ & $\begin{array}{l}\text { A synthetic heart } \\
\text { valve with superior } \\
\text { biocompatibility } \\
\text { and biostability. }\end{array}$ & [80] \\
\hline $\begin{array}{l}\text { Nano- } \\
\text { coating }\end{array}$ & $\begin{array}{l}\text { Stents coated with } \\
\text { magnetizable iron- } \\
\text { platinum } \quad(\mathrm{FePt}) \\
\text { alloy NPs }\end{array}$ & $\begin{array}{l}\text { Chemical } \\
\text { reduction }\end{array}$ & - & $\begin{array}{l}\text { In vitro ability of } \\
\text { the magnetic stent } \\
\text { in stem cell } \\
\text { capture for re- } \\
\text { endothelialization. }\end{array}$ & $\begin{array}{l}\text { Capture of } \\
\text { progenitor stem } \\
\text { cells with high } \\
\text { efficiency. }\end{array}$ & [81] \\
\hline $\begin{array}{l}\text { Nano- } \\
\text { coating }\end{array}$ & $\begin{array}{l}\text { Stents coated with } \\
\text { PLA NPs }\end{array}$ & Electrospinning & Dipyr-idamole & $\begin{array}{l}\text { Tissue } \\
\text { engineering }\end{array}$ & $\begin{array}{l}\text { An efficient drug- } \\
\text { eluting coating onto } \\
\text { stents to cope with } \\
\text { artery thrombosis. }\end{array}$ & [82] \\
\hline $\begin{array}{l}\text { Nano- } \\
\text { coating }\end{array}$ & $\begin{array}{l}\text { Stents coated with } \\
\text { MMSNs and CNTs }\end{array}$ & $\begin{array}{l}\text { Co- } \\
\text { precipitation }\end{array}$ & $\begin{array}{c}\text { Anti-restenotic } \\
\text { agents }\end{array}$ & $\begin{array}{l}\text { A crack-free two- } \\
\text { layered polymer- } \\
\text { free-composite } \\
\text { drug-eluting } \\
\text { coating with }\end{array}$ & $\begin{array}{l}\text { The in vivo study } \\
\text { shows that this } \\
\text { composite coating } \\
\text { has the obvious } \\
\text { advantage of rapid }\end{array}$ & [83] \\
\hline
\end{tabular}




\begin{tabular}{|c|c|c|c|c|c|c|}
\hline & & & & $\begin{array}{l}\text { impressive } \\
\text { network nano- } \\
\text { topologies. }\end{array}$ & $\begin{array}{l}\text { endothelialization } \\
\text { because of its } \\
\text { unique 3D } \\
\text { nanostructured } \\
\text { topology in } \\
\text { comparison with } \\
\text { the commercial } \\
\text { polymer-coated } \\
\text { DES. }\end{array}$ & \\
\hline $\begin{array}{l}\text { Nano- } \\
\text { coating }\end{array}$ & $\begin{array}{l}\text { Angioplasty } \\
\text { balloons coated } \\
\text { with PLGA NPs }\end{array}$ & $\begin{array}{l}\text { Coating by } \\
\text { Layer-by-layer } \\
\text { or acrylic-based } \\
\text { hydrogel } \\
\text { method }\end{array}$ & - & $\begin{array}{l}\text { The transfer } \\
\text { efficacy of NPs } \\
\text { from various } \\
\text { coatings to the } \\
\text { arterial wall was } \\
\text { evaluated in the ex } \\
\text { vivo NP to find the } \\
\text { optimal coating } \\
\text { conditions. }\end{array}$ & $\begin{array}{l}\text { Significantly more } \\
\text { NPs being } \\
\text { transferred to the } \\
\text { rat arterial wall } \\
\text { after the } \\
\text { angioplasty } \\
\text { procedure by the } \\
\text { AAH coating ( } 95 \% \\
\text { transfer efficiency) } \\
\text { compared to that of } \\
\text { the LbL technique } \\
(60 \%) \text { and dip } \\
\text { coating }(20 \%) \\
\text { under flow } \\
\text { conditions } \\
(10 \mathrm{dyn} / \mathrm{cm} 2) \text {. }\end{array}$ & [1] \\
\hline
\end{tabular}

\section{CONCLUSION AND FUTURE PERSPECTIVES}

Nanomaterials as technological drivers of innovation have opened a new avenue in the treatment of CVDa since they can significantly enhance the efficacy of traditional materials. Gradual progress has been observed in cardiovascular biomedical implantation technology in recent years. The use of nanosized drug carriers on implantable stent technology is a promising breakthrough to tackle cardiovascular diseases. Collectively, the use of nanotechnology in a metallic stent surface improves vascular cell responses by means of enhanced adhesion and proliferation of endothelial cells which results in the re-reendothelialization process. This can both mitigate the risk of stent-induced thrombosis and enhance the activity of the treated vessels. Nanoparticles have shown noteworthy potential to offer a platform for targeted delivery of drugs because of their outstanding multi-functionality. Delivering and targeting of a drug to its intended site are the most important characteristics of nanoparticles for the development of successful targeting strategies. However, despite of its beneficial potentials, the future research should consider several points regarding nanotechnology related applications in CVDs. Minimization of toxic effects of the drug, introduction of novel delivery approaches for nanoparticles, and utilization of advanced coating technologies in industrial scale should be warranted. Besides, the interaction of nanoparticles with cells and/or uptake by cells must be specifically studied for any nanoparticles fabricated for clinical applications. Furthermore, nanomaterials are in a high-energy state due to their high surface area to volume ratio, thereby, they tend to agglomerate together to diminish this energy, This gives them special properties like high surface energy. As such, stabilization of nanoparticles with strategies such as the use of stabilizer, surfactant, capping reagents, or controlling the solvent conditions, (e.g. $\mathrm{pH}$ and hydrophilicity/lipophilicity of the dissolution medium) is required. CVD

\section{ACKNOWLEDGMENT}

The authors confirm that this paper was not funded. 


\section{DECLARATION OF INTEREST}

The authors have no relevant affiliations or financial involvement with any organization or entity with a financial interest in or financial conflict with the subject matter or materials discussed in the manuscript. This includes employment, consultancies, honoraria, stock ownership or options, expert testimony, grants or patents received or pending, or royalties. The authors also confirmed that a copy of permissions to use for figures are obtained.

\section{REFERENCES}

1. Iyer, R., et al., Nanoparticle eluting-angioplasty balloons to treat cardiovascular diseases. International journal of pharmaceutics, 2019. 554: p. 212-223.

2. Ma, Z., et al., Nano-lanthanum hydroxide, a novel phosphate binder, for treating hyperphosphatemia: $A$ preclinical study. Biomedicine \& Pharmacotherapy, 2019. 111: p. 909-916.

3. Eftekhari, A., et al., Protective effects of coenzyme Q10 nanoparticles on dichlorvos-induced hepatotoxicity and mitochondrial/lysosomal injury. Environmental toxicology, 2018. 33(2): p. 167-177.

4. Maleki Dizaj, S., et al., Ciprofloxacin HCl-loaded calcium carbonate nanoparticles: preparation, solid state characterization, and evaluation of antimicrobial effect against Staphylococcus aureus. Artificial cells, nanomedicine, and biotechnology, 2017. 45(3): p. 535-543.

5. Hamidi-Asl, E., et al., A Genosensor for Point Mutation Detection of P53 Gene PCR Product Using Magnetic Particles. Electroanalysis, 2015. 27(6): p. 1378-1386.

6. Hamidi-Asl, E., et al., A bimetallic nanocomposite electrode for direct and rapid biosensing of $53 \mathrm{DNA}$ plasmid. Journal of Chemical Sciences, 2015. 127(9): p. 1607-1617.

7. Yazdani, J., et al., A short view on nanohydroxyapatite as coating of dental implants. Biomedicine \& Pharmacotherapy, 2018. 105: p. 553557.

8. Shekoufeh, B., L. Azhar, and F. Lotfipour, Magnetic nanoparticles for antimicrobial drug delivery. Die Pharmazie-An International Journal of Pharmaceutical Sciences, 2012. 67(10): p. 817-821.

9. Sengel, C.T., Delivery of nanoparticles for the treatment of cardiovascular diseases. Global Journal of Obesity, Diabetes and Metabolic Syndrome, 2015. 2: p. 18-21.
10. Jiang, W., et al., Nanomaterials for treating cardiovascular diseases: a review. Bioactive materials, 2017. 2(4): p. 185-198.

11. Prakash, S., et al., Polymeric nanohybrids and functionalized carbon nanotubes as drug delivery carriers for cancer therapy. Advanced drug delivery reviews, 2011. 63(14-15): p. 1340-1351.

12. Dass, C., S. Hallaj-Nezhadi, and F. Lotfipour, Nanoparticle-mediated interleukin-12 cancer gene therapy. Journal of Pharmacy \& Pharmaceutical Sciences, 2010. 13(3): p. 472-485.

13. Rodriguez, P.L., et al., Minimal" Self" peptides that inhibit phagocytic clearance and enhance delivery of nanoparticles. Science, 2013. 339(6122): p. 971-975.

14. Zununi Vahed, S., et al., Targeted cancer drug delivery with aptamer-functionalized polymeric nanoparticles. Journal of drug targeting, 2018(justaccepted): p. 1-22.

15. Salatin, S., S. Maleki Dizaj, and A. Yari Khosroushahi, Effect of the surface modification, size, and shape on cellular uptake of nanoparticles. Cell biology international, 2015. 39(8): p. 881-890.

16. Abbott, N.J., Evidence for bulk flow of brain interstitial fluid: significance for physiology and pathology. Neurochemistry international, 2004. 45(4): p. 545-552.

17. Levy, R.I. and J. Moskowitz, Cardiovascular research: decades of progress, a decade of promise. Science, 1982. 217(4555): p. 121-129.

18. Chandarana, M., A. Curtis, and C. Hoskins, The use of nanotechnology in cardiovascular disease. Applied Nanoscience, 2018: p. 1-13.

19. Schoolaert, E., R. Hoogenboom, and K. De Clerck. Going from polymer to application: ecofriendly solvent electrospinning of optical nanofibrous sensors. in Electrospin 2019. 2019.

20. Fuentes, E., et al., Advanced Surface Treatments on Titanium and Titanium Alloys Focused on Electrochemical and Physical Technologies for Biomedical Applications, in Biomaterial-supported Tissue Reconstruction or Regeneration. 2019, IntechOpen.

21. Przekora, A., The summary of the most important cell-biomaterial interactions that need to be considered during in vitro biocompatibility testing of bone scaffolds for tissue engineering applications. Materials Science and Engineering: C, 2019.

22. Ratner, B.D., Biomaterials: Been There, Done That, and Evolving into the Future. Annual review of biomedical engineering, 2019. 21: p. 171-191.

23. Parnia, F., et al., Overview of nanoparticle coating of dental implants for enhanced osseointegration and antimicrobial purposes. Journal of Pharmacy \& Pharmaceutical Sciences, 2017. 20: p. 148-160.

24. Ahmadian, E., et al., Effect of silver nanoparticles in the induction of apoptosis on human hepatocellular 
carcinoma (HepG2) cell line. Materials Science and Engineering: C, 2018. 93: p. 465-471.

25. Dizaj, S.M., et al., Physicochemical characterization and antimicrobial evaluation of gentamicin-loaded CaCO3 nanoparticles prepared via microemulsion method. Journal of Drug Delivery Science and Technology, 2016. 35: p. 16-23.

26. Samani, A.A. and J. Yazdani, Nanomaterials in Diagnostic Pathology. Journal of advanced chemical and pharmaceutical materials (JACPM), 2019. 2(1): p. 95-96.

27. Rahemi, H. and A. Mennati, Theoretical study of PLA-Cisplatin conjugation. Journal of advanced chemical and pharmaceutical materials (JACPM), 2018. 1(1): p. 10-15.

28. Rahemi, H., Z. Alimohammadi, and K. Khezri, Investigation of the interaction between cisplatin and poly (ethylene glycol) using density functional theory. Journal of advanced chemical and pharmaceutical materials (JACPM), 2018. 1(2): p. 29-33.

29. Jahangiri, A. and L. Barghi, Polymeric nanoparticles: review of synthesis methods and applications in drug delivery. Journal of advanced chemical and pharmaceutical materials (JACPM), 2018. 1(2): p. $38-47$.

30. Habibi, M., et al., Controlled release of Naltrexone using three layered drug-loaded PVA/PLA nanofibrous scaffolds. Journal of advanced chemical and pharmaceutical materials (JACPM), 2018. 1(2): p. 55-61.

31. Salatin, S., et al., An Alternative Approach for Improved Entrapment Efficiency of Hydrophilic Drug Substance in PLGA Nanoparticles by Interfacial Polymer Deposition Following Solvent Displacement. JUNDISHAPUR JOURNAL OF NATURAL PHARMACEUTICAL PRODUCTS, 2018. 13(4).

32. Zununi Vahed, S., et al., Targeted cancer drug delivery with aptamer-functionalized polymeric nanoparticles. Journal of drug targeting, 2019. 27(3): p. 292-299.

33. Labhasetwar, V., et al., Arterial uptake of biodegradable nanoparticles: effect of surface modifications. J Pharm Sci, 1998. 87(10): p. 1229-34.

34. Prabha, S., et al., Size-dependency of nanoparticlemediated gene transfection: studies with fractionated nanoparticles. International Journal of Pharmaceutics, 2002. 244(1): p. 105-115.

35. Luderer, F., et al. Biodegradable Sirolimus-loaded Poly(lactide) Nanoparticles as Delivery Systems for the Prevention of Restenosis in Coronary Stent Application. in World Congress on Medical Physics and Biomedical Engineering, September 7 - 12, 2009, Munich, Germany. 2010. Berlin, Heidelberg: Springer Berlin Heidelberg.

36. Giannouli, M., et al., Fabrication of quercetin-loaded PLGA nanoparticles via electrohydrodynamic atomization for cardiovascular disease. Materials Today: Proceedings, 2018. 5(8): p. 15998-16005.

37. Polizzi, M.A., N.A. Stasko, and M.H. Schoenfisch, Water-soluble nitric oxide-releasing gold nanoparticles. Langmuir, 2007. 23(9): p. 4938-4943.

38. Danenberg, H.D., et al., Macrophage depletion by clodronate-containing liposomes reduces neointimal formation after balloon injury in rats and rabbits. Circulation, 2002. 106(5): p. 599-605.

39. Ruiz-Esparza, G.U., et al., The physiology of cardiovascular disease and innovative liposomal platforms for therapy. International journal of nanomedicine, 2013. 8: p. 629.

40. Bulbake, U., et al., Liposomal formulations in clinical use: an updated review. Pharmaceutics, 2017. 9(2): p. 12.

41. Gao, Y., et al., Prostaglandin E1 encapsulated into lipid nanoparticles improves its anti-inflammatory effect with low side-effect. International journal of pharmaceutics, 2010. 387(1-2): p. 263-271.

42. Zhang, N., et al., Cyclic RGD functionalized liposomes encapsulating urokinase for thrombolysis. Acta biomaterialia, 2018. 70: p. 227-236.

43. Alami-Milani, M., et al., Novel pentablock copolymers as thermosensitive self-assembling micelles for ocular drug delivery. Advanced pharmaceutical bulletin, 2017. 7(1): p. 11.

44. Eniola-Adefeso, O., M.J. Heslinga, and T.M. Porter, Design of Nano Vectors for Therapy and Imaging of Cardiovascular Diseases. Methodist DeBakey cardiovascular journal, 2012. 8(1): p. 13.

45. Gaucher, G., et al., Block copolymer micelles: preparation, characterization and application in drug delivery. Journal of Controlled Release, 2005. 109(1): p. 169-188.

46. Pan, Y., X. Wang, and Z. Yin, Synthesis and evaluation of cationic polymeric micelles as carriers of lumbrokinase for targeted thrombolysis. Asian Journal of Pharmaceutical Sciences, 2018.

47. Gundogdu, E., Z. Senyigit, and D. Ilem-Ozdemir, Nanomedicine for the diagnosis and treatment of cardiovascular disease: current status and future perspective. Cardiovascr Dis I, 2014.

48. Nahrendorf, M., et al., Noninvasive vascular cell adhesion molecule-1 imaging identifies inflammatory activation of cells in atherosclerosis. Circulation, 2006. 114(14): p. 1504-11.

49. Kanno, S., et al., Macrophage accumulation associated with rat cardiac allograft rejection detected by magnetic resonance imaging with ultrasmall superparamagnetic iron oxide particles. Circulation, 2001. 104(8): p. 934-8.

50. Janib, S.M., A.S. Moses, and J.A. MacKay, Imaging and drug delivery using theranostic nanoparticles. Advanced drug delivery reviews, 2010. 62(11): p. 1052-1063. 
51. McCarthy, J.R., F.A. Jaffer, and R. Weissleder, $A$ macrophage-targeted theranostic nanoparticle for biomedical applications. Small, 2006. 2(8-9): p. 9837.

52. Qi, P., M.F. Maitz, and N. Huang, Surface modification of cardiovascular materials and implants. Surface and Coatings Technology, 2013. 233: p. 80-90.

53. Brammer, K.S., et al., Enhanced cellular mobility guided by TiO2 nanotube surfaces. Nano Lett, 2008. 8(3): p. 786-93.

54. Garg, S. and P.W. Serruys, Coronary stents: current status. J Am Coll Cardiol, 2010. 56(10 Suppl): p. S142.

55. Puranik, A., E. Dawson, and N. A Peppas, Recent Advances in Drug Eluting Stents. Vol. 441. 2012.

56. Carpenter, A.W. and M.H. Schoenfisch, Nitric oxide release: part II. Therapeutic applications. Chem Soc Rev, 2012. 41(10): p. 3742-52.

57. Serruys, P.W., M.J. Kutryk, and A.T. Ong, Coronaryartery stents. N Engl J Med, 2006. 354(5): p. 483-95.

58. Westedt, U., et al., Effects of different application parameters on penetration characteristics and arterial vessel wall integrity after local nanoparticle delivery using a porous balloon catheter. Eur J Pharm Biopharm, 2004. 58(1): p. 161-8.

59. Nakano, K., et al., Formulation of NanoparticleEluting Stents by a Cationic Electrodeposition Coating Technology Efficient Nano-Drug Delivery via Bioabsorbable Polymeric Nanoparticle-Eluting Stents in Porcine Coronary Arteries. Vol. 2. 2009. 277-83.

60. Joo, J.-R., et al., A Novel Deposition Method of PLGA Nanoparticles on Coronary Stents. Vol. 30. 2009.

61. Kidane, A.G., et al., A novel nanocomposite polymer for development of synthetic heart valve leaflets. Acta Biomaterialia, 2009. 5(7): p. 2409-2417.

62. Shevach, M., et al., Nanoengineering gold particle composite fibers for cardiac tissue engineering. Journal of Materials Chemistry B, 2013. 1(39): p. 5210-5217.

63. Reed, M.L., et al., Micromechanical Devices for Intravascular Drug Delivery. Journal of Pharmaceutical Sciences, 1998. 87(11): p. 13871394.

64. Wang, Y., et al., Fabrication of a novel polymer-free nanostructured drug-eluting coating for cardiovascular stents. ACS Appl Mater Interfaces, 2013. 5(20): p. 10337-45.

65. Iakovou, I., et al., Incidence, Predictors, and Outcome of Thrombosis After Successful Implantation of Drug-Eluting Stents. Vol. 293. 2005. 2126-30.

66. Oh, S., et al., Significantly accelerated osteoblast cell growth on aligned $\mathrm{TiO} 2$ nanotubes. J Biomed Mater Res A, 2006. 78(1): p. 97-103.
67. Loya, M.C., et al., Plasma-induced nanopillars on bare metal coronary stent surface for enhanced endothelialization. Acta Biomater, 2010. 6(12): p. 4589-95.

68. Jia, H., et al., A novel polymer-free paclitaxel-eluting stent with a nanoporous surface for rapid endothelialization and inhibition of intimal hyperplasia: Comparison with a polymer-based sirolimus-eluting stent and bare metal stent in a porcine model. Vol. 98. 2011. 629-37.

69. Ahmadian, E., et al., Betanin reduces organophosphate induced cytotoxicity in primary hepatocyte via an anti-oxidative and mitochondrial dependent pathway. Pesticide biochemistry and physiology, 2018. 144: p. 71-78.

70. Ahmadian, E., et al., Mechanistic approach for toxic effects of bupropion in primary rat hepatocytes. Drug research, 2017. 67(04): p. 217-222.

71. Qi, C., et al., Hydroxyapatite hierarchically nanostructured porous hollow microspheres: rapid, sustainable microwave-hydrothermal synthesis by using creatine phosphate as an organic phosphorus source and application in drug delivery and protein adsorption. Chemistry, 2013. 19(17): p. 5332-41.

72. Marrella, A., et al., A combined low-frequency electromagnetic and fluidic stimulation for a controlled drug release from superparamagnetic calcium phosphate nanoparticles: potential application for cardiovascular diseases. Journal of The Royal Society Interface, 2018. 15(144): p. 20180236.

73. Ferreira, M.P., et al., Drug-Loaded Multifunctional Nanoparticles Targeted to the Endocardial Layer of the Injured Heart Modulate Hypertrophic Signaling. Small, 2017. 13(33): p. 1701276.

74. Nguyen, N., et al., Targeted Nanoparticles Serve as Effective Drug Delivery Vehicles for CardiovascularBased Therapy. Circulation, 2016. 134(suppl_1): p. A20028-A20028.

75. Yu, J., W. Li, and D. Yu, Atrial natriuretic peptide modified oleate adenosine prodrug lipid nanocarriers for the treatment of myocardial infarction: in vitro and in vivo evaluation. Drug design, development and therapy, 2018. 12: p. 1697.

76. Nahrendorf, M., et al., Nanoparticle PET-CT imaging of macrophages in inflammatory atherosclerosis. Circulation, 2008. 117(3): p. 379.

77. Kelly, K.A., et al., Detection of vascular adhesion molecule-1 expression using a novel multimodal nanoparticle. Circulation research, 2005. 96(3): p. 327-336.

78. Ni, N.C., et al., Non-invasive macrophage tracking using novel porphysome nanoparticles in the postmyocardial infarction murine heart. Molecular Imaging and Biology, 2016. 18(4): p. 557-568.

79. van Tilborg, G.A., et al., Annexin A5-functionalized bimodal nanoparticles for MRI and fluorescence 
imaging of atherosclerotic plaques. Bioconjugate chemistry, 2010. 21(10): p. 1794-1803.

80. Jia, H., et al., A novel polymer-free paclitaxel-eluting stent with a nanoporous surface for rapid endothelialization and inhibition of intimal hyperplasia: Comparison with a polymer-based sirolimus-eluting stent and bare metal stent in a porcine model. Journal of biomedical materials research Part A, 2011. 98(4): p. 629-637.

81. Lee, J., et al., Magnetically coated bioabsorbable stents for renormalization of arterial vessel walls after stent implantation. Nano letters, 2017. 18(1): p. 272-281.

82. Bakola, V., et al., Dipyridamole-loaded biodegradable PLA nanoplatforms as coatings for cardiovascular stents. Nanotechnology, 2018. 29(27): p. 275101.

83. Wang, Y., et al., Fabrication of a novel polymer-free nanostructured drug-eluting coating for cardiovascular stents. ACS applied materials \& interfaces, 2013. 5(20): p. 10337-10345.

84. Nemmar, A., et al., Ultrasmall superparamagnetic iron oxide nanoparticles acutely promote thrombosis and cardiac oxidative stress and DNA damage in mice. Vol. 13. 2016. 22.

85. Sun, Z., et al., Nano Zerovalent Iron Particles Induce Pulmonary and Cardiovascular Toxicity in an in Vitro Human Co-Culture Model. Vol. 10. 2015. 1-47.

86. Chen, Z., et al., Effect of titanium dioxide nanoparticles on the cardiovascular system after oral administration. Vol. 239. 2015.

87. Kang, B., M. A Mackey, and M. El-Sayed, Nuclear Targeting of Gold Nanoparticles in Cancer Cells Induces DNA Damage, Causing Cytokinesis Arrest and Apoptosis. Vol. 132. 2010. 1517-9.

88. Bussy, C., L. Methven, and K. Kostarelos, Hemotoxicity of carbon nanotubes. Adv Drug Deliv Rev, 2013. 65(15): p. 2127-34. 